\title{
Russian Economic Pressures and Energy Stakes in the EU
}

\section{Eastern Neighbourhood}

\author{
Ioana Sandu ${ }^{1 *}$ \\ ${ }^{1}$ Bucharest University of Economic Studies, Bucharest, Romania \\ *Ioana Sandu, E-mail: ioanamarina18@yahoo.com
}

\begin{abstract}
Perceived by the six small countries of the Eastern Partnership as one of their most fearsome adversary, Russia has permanently made its presence visible, all the more in its proximity. Thus, Russian energy resources, that most of the EU members and neighbours covet, have been the subject of numerous debates on the trajectory of energy corridors and have amplified the EU pursuit of developing its own energy strategy and reducing dependence on exterior resources.

Caught in the middle, the "sandwiched" Eastern partners have chosen either to cooperate economically and join the EU side, or to stumble and hesitate between the two, or to adhere to their direct enemy, by joining the Eurasian Economic Union. Regardless of their option, they all try to balance their economic profile with the geopolitical context and to adjust their policies so that they gain a respectful status in the region.
\end{abstract}

\section{Keywords}

energy, security, resources, infrastructure

\section{Introduction}

The Eastern Partnership (EaP)—derived from the European Neighbourhood Policy—was created in 2009 by including the EU Eastern neighbours (Armenia, Azerbaijan, Belarus, Georgia, Moldova and Ukraine), that are geographically linked to Eastern Europe and South Caucasus, a region of soviet heritage, bordering both the EU and Russia.

The six small states have undergone historical conflicts leading to separatist areas on their territories, but also serious political instability and economic weaknesses. Despite these drawbacks, they have been continuously hunted by major powers in the area, namely the EU and Russia.

Current events in Ukraine have indicated a sense of Russian irritation towards Ukraine, when the country decided to follow the EU approximation path. However, in June 2014, Ukraine, Moldova and Georgia "legalized" their relation with the EU by signing Association Agreements (AA), including Deep and Comprehensive Free Trade Areas (DCFTA).

This is the lens through which we aim to identify what the Russian interests in the area are and how they reflect into the situation of the $\mathrm{EaP}$ countries, from an economic perspective given by 
developments and stakes in the energy sector and not only.

Our analysis will first go through the legal cooperation framework in the field, as well as energy infrastructure affecting the EaP countries (Black Sea Synergy, The European Energy Security Strategy and energy corridors). The second section covers features of the Eurasian Economic Union, seen as a Russian initiative very similar to the $\mathrm{EU}$, an attempt to preserve or rather to regain a dominant position on the international arena.

The article refers to official EU documents issued on the Eastern Partnership and the above mentioned initiatives, but also analytical studies on the matter. Our presumption is that Russia's influence on the EaP countries is exerted less officially, but rather in a more subtle, yet coercive way.

\section{Energy Corridors-Implications for the Eastern Partnership Countries}

\subsection{Black Sea Synergy and the Eastern Partnership Countries}

Created with the purpose of an increased cooperation between states bordering the Black Sea, the Black Sea Synergy (BSS) is an EU initiative including three Member States (Romania, Greece, Bulgaria), five of the six EaP members (Armenia, Azerbaijan, Georgia, Moldova and Ukraine) and Turkey and Russia, states holding an obvious stake in the region. It was officially launched in Kyiv in February 2008, following a proposal of the European Commission (EC) to the European Parliament and Council from April 2007 (European Commission, 2007).

With the EU support through the European Neighbourhood Policy (ENP), the pre-accession policy and the Strategic Partnership with Russia, the BSS purpose is "the development and interconnection of transport, energy and communication infrastructure, responding to increasing trade, investment, traffic and information flows as well as rapidly evolving transit needs" (EEAS, 2008, p. 1).

BSS is encouraging dialogue between energy producers, consumers and transit countries in order to contribute to energy security and sustainable development, targeting environment protection and fishery, but also trying to prevent natural and manmade disasters and to resolve protracted conflicts in the area. Energy stability is a key issue both within the EU and in the particular case of the BSS partners. A new trans-Caspian trans-Black Sea energy corridor would provide the infrastructure for additional gas exports from Central Asia through the Black Sea towards the EU. Moreover, large amounts of oil crossing the Black Sea have brought concern over potential environmental accidents, which further led to developing EU cooperation with ecological and sustainable features (European Commission, 2007). The BSS activity report, published in January 2015, emphasizes the initiative achievements, but also the special place held by Russia and Azerbaijan, whose resources are up to 33 and 1 trillion cubic meters of natural gas and to 87 and 7 thousand million barrels of oil respectively (European Commission, 2015). At the same time, the two countries are the main energy trading partners of the EU: Russia holds 35\% of the EU oil imports and 30\% of the EU gas imports, whereas Azerbaijan covers for the moment 5\% of the total EU oil imports (Eurostat, April 2013), but its role as a natural gas provider for the EU is expected to increase in the future.

Published by SCHOLINK INC. 
In addition, the BSS activity report emphasizes the importance of developing energy from renewable sources (hydro, solar and wind power), but also of constructing new pipelines and adapting existent ports to meet increased traffic and energy demands.

Related activities are also supported; for example, the "Baku Initiative", created in 2004 as an energy cooperation forum between countries bordering the Black Sea and the Caspian Sea, has been financed through the INOGATE programme (international energy cooperation involving the EU, Azerbaijan, Armenia, Belarus, Georgia, Kazakhstan, Kyrgyzstan, Moldova, Tajikistan, Turkmenistan, Ukraine and Uzbekistan) and extended for 2012-2015 (European Commission, 2015).

However, the development of such initiatives, contributing to the energy cooperation framework, has rendered the BSS second in the EU priorities in recent years.

\subsection{The European Energy Security Strategy and the EU Eastern Neighbourhood}

Given the importance of the energy sector in the EU Eastern neighbourhood, both economically and from a security environment perspective, the need for a European Energy Community has emerged in 2000 and has fleshed out through the signing of The Energy Community Treaty in October 2005.

The European Energy Community (EEC) now comprises 20 of the 28 Member States, but also states of the neighbourhood, such as the Western Balkans states (Note 1), Moldova and Ukraine as contracting parties (from 2010 and 2011 respectively), Turkey, Armenia (from 2011) and Norway as observers and Georgia as a candidate country. From the EaP members, Belarus and Azerbaijan are currently outside the EEC (Energy Community portal, 2016).

The Energy Union addresses not only classic energy sources: oil, natural gas and electricity but also related matters such as energy efficiency, competition, statistics, security of supply, infrastructure, renewable energy, environment and social issues.

EEC extends the EU energy policy to European South-Eastern countries and some countries in the Black Sea region, aiming to create integrated energy markets and attract investments to improve security of supply. Ukraine, Moldova and Georgia have signed Association Agreements (AA) involving Deep and Comprehensive Free Trade Areas (DCFTA) with the EU in June 2014. Thus they benefit from a higher degree of approximation to the EU energy legislation. Turkey is targeting a similar result following its rapprochement to the EU, while Russia is considered a strategic partner in creating a pan-European energy market by 2050 (European Commission, 2015).

Consequently, the EU dependency on exterior energy resources, along with lingering tensions with Russia in the Eastern neighbourhood, have led to the creation of an European Energy Security Strategy (EESS), which would allow Member States that rely on a single external supplier (especially Germany and Italy for natural gas, Baltic states for electricity)—normally Russia—to find alternative supplies and thus decrease the risk of major shocks and disruptions of energy supply.

Based on the solidarity principle, the EESS identifies eight pillars of the EU energy security, designed to ensure a closer cooperation between members, equally respecting their national energy options (European Commission, 2014): 
- Immediate actions to increase the EU capacity to overcome a major disruption for the 2014/2015 winter (stress tests, increasing gas stocks);

- $\quad$ Securing emergency/solidarity mechanisms, risk assessment and contingency plans; protecting strategic infrastructure;

- $\quad$ Moderating energy demand;

- $\quad$ Building a fully integrated internal market (reaching an interconnection threshold of $15 \%$ by 2030);

- $\quad$ Increasing energy production in the $\mathrm{EU}$;

- $\quad$ Further developing energy technologies (financed during the 2014-2020 sequence through: the European Regional Development Fund, the European Neighbourhood Policy Instrument, the "Connecting Europe" Facility, Horizon 2020, the Neighbourhood Investment Facility, the Western Balkans Investment Facility, the European Investment Bank and the European Bank for Reconstruction and Development);

- Diversifying external supplies and related infrastructure (a reinforced partnership with Norway, the Southern Corridor, promotion of a new gas hub in Southern Europe);

- Improving coordination of national energy policies.

\subsection{Energy Corridors and Their Importance for the Eastern Partnership Countries}

For states in the Eastern neighbourhood, that are the most affected by dependency on Russian energy resources, the existence and configuration of the crossing energy corridors are highly important.

For instance, Georgia benefited from the "Black Sea Regional Transmission Network" project (completed in December 2013), which supported the development of an electricity network in the Caucasus and increased the interconnecting capacity between Georgia and Turkey. Its success determined the planning of a similar project between Georgia and Armenia.

The Romania-Moldova gas interconnector (opened in August 2014), is also part of a larger project aiming to connect Moldova's capital region, Kishinev, to the Romanian natural gas network.

The Southern Corridor (see map in Figure 1) is designed to initially transport an annual amount of 10 billion cubic meters of natural gas from Azerbaijan to the EU market by 2020. It will link the gas deposits in Shah Deniz II Baku (Azerbaijan) to Italy, by crossing Georgia, Turkey, Greece and Albania (Trans Adriatic Pipeline portal, 2016). Its construction will contribute to increasing security of supply for the countries involved, but also in general for Member States and for the South-Eastern Europe. Additionally, the Southern Corridor might include other gas transport options such as the White Stream (gas pipeline through the Black Sea) and AGRI (gas pipeline from Azerbaijan to Georgia, followed by liquefied natural gas transport through the Black Sea).

The Southern Corridor has emerged as an alternative to Southstream, a gas pipeline about to link Russia to Central and Eastern Europe. Southstream has been abandoned in January 2015, because the European Commission has reported that the project did not comply with the EU gas legislation (Dumitrescu, 2015). 


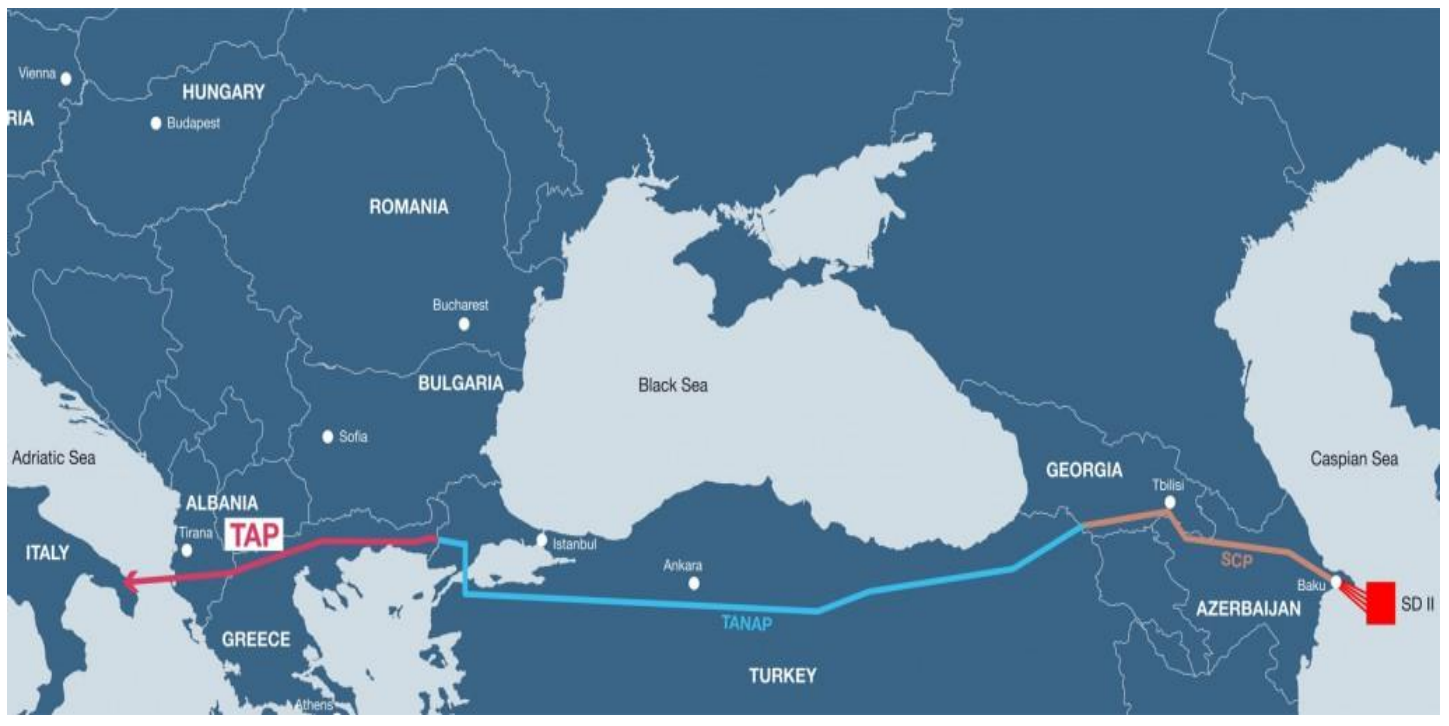

Figure 1. Southern Corridor Map (Subsea World News, 2013)

In support of the EU members and neighbours, the EESS was prepared in May 2014 and introduced a series of actions that have been implemented since the 2014/2015 winter; the European Commission and the Member States have created stress tests for energy security, with the purpose of developing new solidarity mechanisms for increasing gas storage capacity (European Commission, 2014).

The EU is thus promoting energy security towards its Eastern partners: the reverse flow agreement between Slovakia and Ukraine is encouraged by the EU through the EESS. Moreover, in February 2015, the EU has created a High Level Group on Central and South Eastern Europe Gas Connectivity (CESEC), in order to develop markets and diversify energy supply, involving Austria, Bulgaria, Croatia, Greece, Hungary, Italy, Romania, Slovakia and Slovenia.

CESEC projects (European Commission, 2016) include, inter alia, some features for the Eastern Partnership members, such as:

- $\quad$ Extension of Romania - Republic of Moldova interconnection (Iași-Ungheni);

- $\quad$ Physical reverse flow Romania —Ukraine (at interconnection point Isaccea);

- $\quad$ Firm capacity upgrade on the interconnector Hungary-Ukraine.

At the same time, Eastring (linking Bulgaria and Slovakia) and Tesla (linking Greece and Austria) are considered by the European Commission as common interest projects, although Tesla is considered a pillar of Turkish Stream, gas interconnector supported by Gazprom, the giant Russian company (Geropulos, 2015).

\section{The Eurasian Economic Union: Russia's Answer to the Eastern Partnership?}

Currently, the Eurasian Economic Union (EEU) includes, beside Russia, smaller states in the post-soviet bloc: Armenia, Belarus, Kazakhstan and Kyrgyzstan. The first mention of a Eurasian Union dates back to 1994, but, after preliminary stages, the Treaty establishing the Eurasian Economic Union 
was signed in May 2014 by Russian, Kazakhstani and Belarusian leaders, Armenia and Kyrgyzstan joining the EEU later on that year, in October and December respectively.

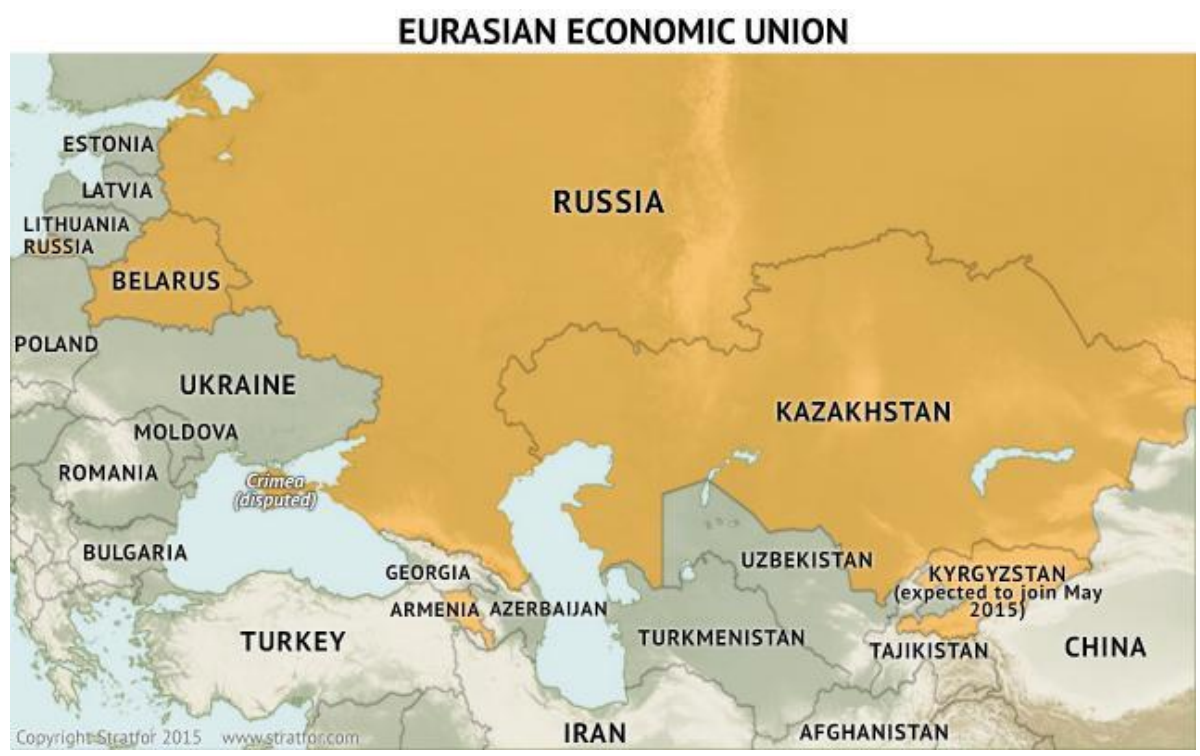

Figure 2. The Eurasian Economic Union (Stratfor, 2015)

The EEU mandate is to "provide for free movement of goods, services, capital and labor" and also "comprehensively upgrade, raise the competitiveness of and cooperation between the national economies, and to promote stable development in order to raise the living standards of the nations of the Member-States" (EEU website, 2016).

However, there are voices to support the idea of the EEU creation as an attempt to recompose the ex-soviet space in a "new Eurasia" (Popescu, 2014, p. 34), although the geopolitical and ideological Eurasia as the Putin administration perceives it is not the same as the real Eurasia, much smaller in size and economic power. Russia's expansionist ambitions and their expression during the Ukraine war have thwarted the former's efforts to create an extended and powerful economic area in the EU close neighbourhood.

The Eastern Partnership members refer differently to EEU, namely:

- Azerbaijan preserved a certain neutrality, trying to be friendly to both sides, its attitude also being supported by the economic independence brought by its natural gas reserves and the Southern Corridor perspective.

- Armenia decided shortly before signing the AA/DCFTA (already negotiated) with the EU in 2013 to refocus on the EEU. This decision did not hamper the resumption of negotiation with the EU, at the end of 2015, with the purpose of signing a new agreement, matching the state's current commitments within the EEU. 
- Georgia and Moldova have proved to be the most committed performers in the Eastern Partnership, by scrupulously following reforms assumed through the signing of AA/DCFTA with the EU in 2014; their decision was taken despite indirect pressures from Russia through the conflict in Ukraine, but also Russian economic sanctions that the two countries have faced over time. The multiple Russian embargoes (for instance the well-known embargo in 2006 on Moldovan wines) have led to a decreased trade dependency on Russia, on the one hand, and a moving off the EEU, on the other hand (Popescu, 2014).

- Ukraine has tried to negotiate its membership in the Eastern Partnership with Russia, but the result was firm and Russia's retaliation was violent; however, Ukraine continued to follow its road towards the EU approximation, and humanitarian and financial aid for surpassing the sequels of the Crimean war and from the Provinces Luhansk and Donetsk.

The establishment of the EEU follows the EU model, its final purpose being to become a Eurasian Union in the future. However, trade flows for states in the Eastern neighbourhood of the EU are mostly heading towards the EU members. Russia employs higher tariffs than those of the EEU partners, thus the latter encounter higher costs when importing from the EU and China (Popescu, 2014).

Discrepancies between Russia's economic power and the situation of other EEU members, but also the alleged gains of the EEU membership, which are slightly overdue (Putz, 2016), raise serious doubts on the so-called emergence of EEU as an economic power comparable to the EU in the near future.

Perspectives on the future EU-EaP-Russia relations are also alarming, as the geopolitics of the EaP members continues to reshape and Russia will probably not give up on exerting its military power in the region (Haukkala \& Popescu, 2016).

\section{Conclusions}

Energy puzzles in the EU Eastern neighbourhood have gained more importance with the increasing tensions in Ukraine since 2014. Russia has proved once again that questioning its status in the area might generate discontent or even counteroffensive, either indirectly (economic pressures, creation of the Eurasian Economic Union in May 2014) or even with military intervention when threatened.

On its side, the EU intensified the Energy Community project emerged in 2005. Firstly, the Black Sea Strategy (2008) regrouped some of the Eastern Partnership members, EU members as well as Russia and Turkey with the purpose of a peaceful regional cooperation.

In a few years though, the focus was more on creating an Energy Union that would help reduce energy dependency on external suppliers (mostly Russia). The EaP members gradually joined the EU approach: Moldova and Ukraine became contracting parties of the Energy Community in 2010 and 2011; Armenia was also included in 2011, whereas Georgia is a candidate country. The peak so far was the European Energy Security Strategy, emerged in May 2014, most probably not as a coincidence at the same time with the EEU.

Simultaneously, energy corridors and local initiatives switching from Southstream (involving Russia, 
abandoned in January 2015) to the Southern Corridor (involving Azerbaijan, supported by the European Commission) and the creation of a Central and South Eastern Europe Gas Connectivity have once more vouched the indirect race to economic supremacy over the Eastern Partnership countries that both the EU and Russia claim to be winning.

\section{References}

Dumitrescu, A. (2015, January 14). The Gazprom Leader: South Stream is a Closed Project [Șeful Gazprom: South Stream este un proiect închis]. Retrieved April 28, 2016, from http://www.mediafax.ro/economic/seful-gazprom-south-stream-este-un-proiect-inchis-13765950

Energy Community portal. (2016). Members. Retrieved April 25, 2016, from https://www.energy-community.org/portal/page/portal/ENC_HOME/MEMBERS

Eurasian Economic Union website. (2016). Retrieved May 1, 2016, from http://www.eaeunion.org/?lang=en\#about

European Commission. (2007). Black Sea Synergy -A New Regional Cooperation Initiative. COM (2007) 160 final. Retrieved March 7, 2016, from http://www.eur-lex.europa.eu/LexUriServ/ LexUriServ.do?uri=COM:2007:0160:FIN:EN:PDF

European Commission. (2014). European Energy Security Strategy. COM (2014) 330 final. Retrieved April 25, 2016, from http://www.eur-lex.europa.eu/legal-content/EN/TXT/PDF/?uri= CELEX:52014DC0330\&from=EN

European Commission. (2015). Black Sea Synergy: Review of a regional cooperation initiative. SWD (2015) 6 final. Retrieved April 25, 2016, from http://www.eeas.europa.eu/blacksea/doc/ swd_2015_6_f1_joint_staff_working_paper_en.pdf

European Commission. (2016). Central and South Eastern Europe Gas Connectivity. Retrieved April 26, 2016, from http://www.ec.europa.eu/energy/en/topics/infrastructure/central-and-southeastern-europe-gas-connectivity

European External Action Service. (2008). Joint Statement of the Ministers of Foreign Affairs of the countries of the European Union and of the wider Black Sea area. Retrieved April 25, 2016, from http://www.eeas.europa.eu/blacksea/doc/joint_statement_blacksea_en.pdf

Geropulos, K. (2015, November 20). EU Fast-Tracks Tesla, Eastring Gas Lines. Retrieved April 26, 2016, from http://www.energia.gr/article_en.asp?art_id=29932

Haukkala, H., \& Popescu, N. (2016). Russian futures: Horizon 2025. European Union Institute for Security Studies. Retrieved April 26, 2016, from http://www.iss.europa.eu/uploads/ media/Report_26_Russia_Future_online..pdf

Popescu, N. (2014). Eurasian Union: The real, the imaginary and the likely. European Union Institute for Security Studies. Retrieved April 26, 2016, from http://www.iss.europa.eu/uploads/media/CP_132.pdf

Putz, C. (2016). A “Blurry Union”: Kyrgyzstan and the Eurasian Economic Union. Retrieved April 26, Published by SCHOLINK INC. 
2016, from http://www.thediplomat.com/2016/02/a-blurry-union-kyrgyzstan-and-the-eurasianeconomic-union/

Subsea World News. (2013, December 17). Shah Deniz Stage 2 and SCP Expansion Projects Announced. Retrieved April 27, 2016, from http://www.subseaworldnews.com/ 2013/12/17/shah-deniz-stage-2-and-scp-expansion-projects-announced/

Trans Adriatic Pipeline portal. (2016). Southern Gas Corridor. Retrieved April 27, 2016, from http://www.tap-ag.com/the-pipeline/the-big-picture/southern-gas-corridor 